Article

\title{
Regional Ecological Risk Assessment of Wetlands in the Sanjiang Plain with Respect to Human Disturbance
}

\author{
Hui Wang ${ }^{1,2}$, Changchun Song ${ }^{2, *}$ and Kaishan Song ${ }^{2}$ \\ 1 College of Tourism and Geography, Jiujiang University, Jiujiang 332005, China; wanghuipku110@163.com \\ 2 Key Laboratory of Wetland Ecology and Environment, Northeast Institute of Geography and Agroecology, \\ Chinese Academy of Sciences, Changchun 130102, China; songks@iga.ac.cn \\ * Correspondence: songcc@iga.ac.cn
}

Received: 31 December 2019; Accepted: 27 February 2020; Published: 5 March 2020

check for updates

\begin{abstract}
Characterization of the intensity of regional human disturbances on wetlands is an important scientific issue. In this study, the pole-axis system (involving multi-level central places and roads) was recognized as a proxy of direct risk to wetlands stemming from human activities at the regional or watershed scale. In this respect, the pole-axis system and central place theory were adopted to analyze the spatial agglomeration characteristics of regional human activities. Soil erosion and non-point source (NPS) pollution, indicating the indirect effect of human activities on wetlands, were also considered. Based on these human disturbance proxies, which are considered regional risk sources to wetlands, incorporated with another two indicators of regional environment, i.e., vulnerability and ecological capital indexes, the regional ecological risk assessment (RERA) framework of wetlands was finally established. Using this wetland RERA framework, the spatial heterogeneity of risk grades within the Naoli River Basin, a typical concentrated wetland region in the Sanjiang Plain, was analyzed. The results showed that (1) high- and very high-risk source intensity areas displayed a ring-shape distribution pattern, which reflected the influence of the regional pole-axis system; (2) owing to their high ecological capital value per unit area and vulnerability level, the wetlands had the highest risk grade, as did central places (i.e., those areas where county seats and administration bureaus of farms were located). In terms of proportion, the low-, medium-, high-, and very high-risk areas accounted for $72.0 \%, 16.8 \%, 10.1 \%$, and $1.1 \%$ of the study area, respectively. The identification and classification of risk sources to wetlands that are related to human activity at the watershed scale could provide clear perspectives in order to reduce severe risk sources to these areas, especially those Ramsor Convention-appointed sites of international importance. Moreover, the assessment framework used in this paper will provide a helpful reference for related research in the future. Finally, the new management guidelines proposed in this paper will be beneficial for lowering the ecological risk level of wetlands at the watershed or regional scale for the Sanjiang Plain or other wetland-concentrated regions.
\end{abstract}

Keywords: regional ecological risk assessment (RERA); human activities; pole-axis system; direct ecological risk; indirect ecological risk; wetland; Naoli River Watershed

\section{Introduction}

With the "zero-risk environmental management" concept having been proven too rigid, since the 1980s, ecological risk management (ERM) has become increasingly popular, as it accepts certain degrees of environmental risk [1-4]. In general, ERM refers to the probability and consequences of damage affecting ecosystem structure and function caused by human activities and climate change [3]. With the 
development of ERM, ecological risk assessment (ERA), which provides a scientific foundation for ERM so that eco-environmental damage can be minimized, has become the focus of related research [5]. Specifically, ERA is a process evaluating potential adverse effects associated with one or more possible eco-environmental hazards stemming from human activities and climate change [6]. ERA research has three important characteristics: (1) Emphasis on the uncertainty of ecological risk; (2) an orientation from after-loss recovery to before-loss prevention; and (3) a focus on controlling ecological deterioration at its source [1]. Based on its development history, ERA can be divided into several sub-phases in order: the budding stage, the human health assessment stage, the ERA stage, and the regional ERA (RERA) stage [7]. Overall, ecological risk assessment shifts gradually from single-risk to multi-risk (containing risk sources and receptors) assessment and from the local to regional and landscape scale. The RERA is one branch of general ERA, considering the co-occurrence of both risk sources and risk receptors, and focuses on spatial heterogeneity analysis of ecological risk at the regional scale [3]. A number of methodologies have been developed in the RERA field [8], such as the "Three-Step Framework" formulated by the United States Environmental Protection Agency [6,9], the Relative Risk Model (RRM) by Landis and Wiegers [10], the Procedure for Ecological Tiered Assessment of Risk (PETAR) by Moraes et al. [11], and the wetland RERA method by $\mathrm{Xu}$ et al. [3]. Among them, the wetland RERA method is a useful framework for wetland ecological risk assessment at the regional scale, incorporating the merits of other methods such as the normalization of multi-risk source-receptor factors of RRM, the grading of PETAR, and the analysis process division of the "Three-Step Framework" [3,4]. The RERA plays an important role in both theoretical support and practical guidance for regional sustainable development [12].

Wetlands, which have the highest number of ecosystem services per unit area, are essential to human survival and sustainable development [13]. As an important carbon bank of terrestrial ecosystems, around $20 \%-30 \%$ of total organic carbon is stored in wetlands globally; carbon balance concerns are closely related to climate change $[14,15]$. However, with the development of urbanization, industrialization, and population growth, wetland areas are declining, and their functions are degraded in many parts of the world [5,16-19]. Human activities can influence the structure and function of wetlands in multiple ways. The survey results of key wetlands in China indicated that $95.2 \%$ of wetlands within the country were threatened by human activity, among which $30.3 \%$ was reclaimed or transformed at random, $26.1 \%$ were affected by pollution, $24.2 \%$ were affected by excessive biological resource use, $8.0 \%$ were degraded by soil and water loss and sediment deposition, and $6.6 \%$ were degraded by unreasonable water resource use [20]. These human disturbances to wetlands can be divided into two categories: direct and indirect (Table 1). The direct influence includes reclamation and human activities occurring within the scope of wetlands, such as wetland tourism, excessive use of biological resources (bird eggs, fish, reeds, etc.), and harvesting of water resources from wetlands for irrigation. The risk to wetlands stemming from the direct effect of human activity is related to the distribution of settlements (multi-level central places, e.g., cities, towns, villages), which are areas of human activity that are aggregated spatially. Normally, people leave a certain settlement point for a certain wetland area to gain in natural resources, to view/enjoy the wetlands, and to reclaim unused land areas. Thus, the distribution of settlements could affect the ecosystem of adjacent wetlands [21]. Direct risk also stems from roads, which affect the accessibility of wetlands. The sources of direct risk can also be referred to as the pole-axis system [22]. The intensity of human activities and the scope of their services are generally larger when the grade of the central place is higher, and vice versa [21]. For central places at a higher level, the damage probability and risk grade imposed on regional ecosystems (e.g., forests, croplands, grassland, and wetlands) will be greater. Likewise, the regional axis system is usually regarded as a stressor, i.e., risk source, leading to hazards to ecosystem structure and function, such as loss of biodiversity [23] and groundwater recharge potential (which is important for regional groundwater environment health [24]). In wetland areas, the axis system influences the convenience of obtaining resources for multi-level central places and also the spatial accessibility of different areas (including wetlands) within the region, which plays an important role in the risk of 
events within the scope of certain sites in the region. On the other hand, the indirect human-caused sources of risk to wetlands, especially the chemical pollution of wetlands (e.g., heavy metal [25-29] and pesticide contamination [30]) represent a research hotspot within the wetland ecological risk assessment field. In this study, the indirect influence indicates that part of human activities, which can cause pollution or sediment deposition of wetlands through material linkage (chemical substances, such as compounds of nitrogen and phosphorus, and sand) between wetland and non-wetland area spatially. The sand deposition and pollution of nitrogen and phosphorus can damage the health of wetlands in many ways, such as plant succession, stability of wetland carbon pool, and so on [31-33]. As these human activities happen outside the scope of wetlands, which means they normally take place in upstream cropland and forestland region of wetlands, they could be grouped into the indirect risk source of wetlands in this study (Table 1). The material linkage between wetlands and non-wetland areas embodies soil and nutrient substance loss for forestland and cropland, and sediment deposition and the non-point source (NPS) pollution (addition of nitrogen and phosphorus) for wetlands [34].

Table 1. Classification of human-caused ecological risk of wetlands in this study.

\begin{tabular}{|c|c|c|c|c|c|}
\hline & $\begin{array}{l}\text { Where Human } \\
\text { Activities } \\
\text { Happen }\end{array}$ & $\begin{array}{l}\text { What Enters the } \\
\text { Scope of Wetlands }\end{array}$ & $\begin{array}{c}\text { Wetland } \\
\text { Risk Events }\end{array}$ & $\begin{array}{l}\text { Where People/Materials } \\
\text { Come from }\end{array}$ & Proxy \\
\hline $\begin{array}{l}\text { Human-caused } \\
\text { direct risk } \\
\text { on wetlands }\end{array}$ & $\begin{array}{l}\text { Inside of } \\
\text { the scope } \\
\text { of wetlands }\end{array}$ & People & $\begin{array}{c}\text { Reclamation } \\
\text { Biological resources' } \\
\text { excessive use } \\
\text { Water resources' } \\
\text { unreasonable use } \\
\text { Tourism }\end{array}$ & $\begin{array}{l}\text { Regional pole-axis system, } \\
\text { i.e., nearby multi-level central } \\
\text { places, through } \\
\text { multi-level roads }\end{array}$ & $\begin{array}{l}\text { DMSP-OLS nighttime } \\
\text { light intensity index and } \\
\text { normalized density of } \\
\text { multi-level roads }\end{array}$ \\
\hline $\begin{array}{l}\text { Human-caused } \\
\text { indirect risk } \\
\text { on wetlands }\end{array}$ & $\begin{array}{l}\text { Outside of the } \\
\text { scope of } \\
\text { wetlands }\end{array}$ & $\begin{array}{l}\text { Materials, e.g., sand, } \\
\text { compounds of nitrogen } \\
\text { and phosphorus }\end{array}$ & $\begin{array}{c}\text { Pollution } \\
\text { Sediment deposition }\end{array}$ & $\begin{array}{l}\text { Upstream non-wetland } \\
\text { ecosystems, e.g., forestland, dry } \\
\text { cropland, and paddy fields }\end{array}$ & $\begin{array}{l}\text { Soil erosion grades and } \\
\text { NPS pollution level }\end{array}$ \\
\hline
\end{tabular}

Therefore, using the Defense Meteorological Program Operational Line-Scan System (DMSP-OLS) nighttime light intensity and multi-level roads data (multi-level central places and roads, a proxy of direct influence of human activities on ecosystems especially wetlands in regional scale) and soil erosion grades and the NPS pollution data (a proxy of indirect influence of human activities on wetlands in regional scale), incorporated with the other two indicators of regional environment, i.e., vulnerability and ecological capital indexes, the wetland RERA issue was researched in this study. In this research, a typical wetlands-concentrated watershed within the Sanjiang Plain, the Naoli River Watershed, was selected to practice the RERA research model proposed in this paper. On the basis of assessment results, we further put forward a series of countermeasures with respect to the risk reduction and prevention in the watershed. The results of this study will be an important warning, as well as a practical guide, for the protection and sustainable development of wetlands in the Naoli River Basin.

\section{Materials and Methods}

\subsection{Study Area}

The Naoli River Watershed $\left(131^{\circ} 31^{\prime}-134^{\circ} 10^{\prime} \mathrm{E}, 45^{\circ} 43^{\prime}-47^{\circ} 35^{\prime} \mathrm{N}\right)$ is situated in the heart of the Sanjiang Plain. The Wanda Mountain is its southeast boundary, whereas the Wusuli River forms its east boundary. The total area of the whole catchment is $22,540 \mathrm{~km}^{2}$, which is about $25 \%$ of the Sanjiang Plain, including $61.7 \%$ occupied by plain area and 38.3\% mountainous and hilly area [35]. In terms of administrative division, the Naoli River Watershed includes Baoqing County, Youyi County and parts of Fujin County, Raohe County, Jixian County, Shuangyashan City, and Qitaihe City (Figure 1). 


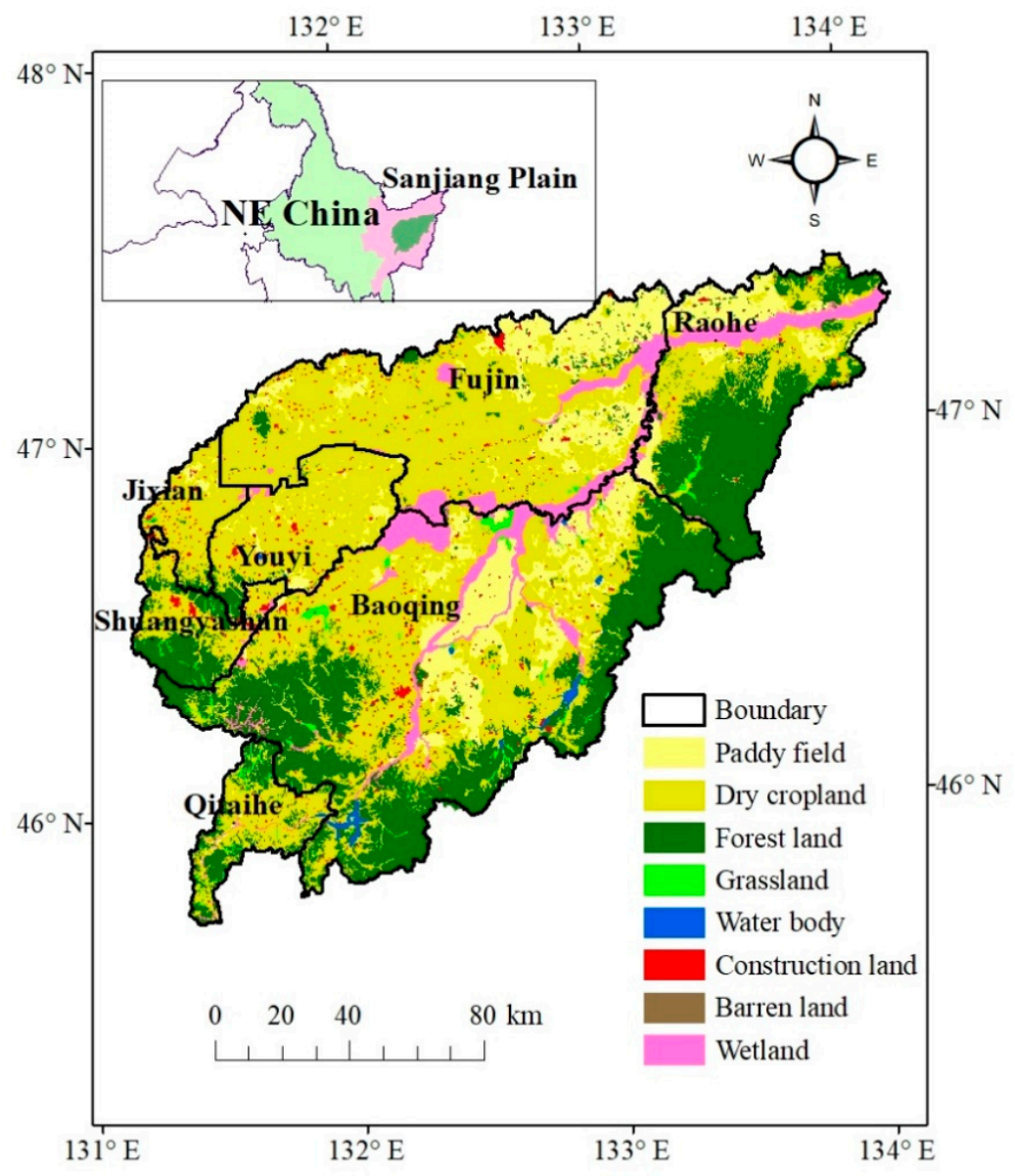

Figure 1. Location of study area with the distribution of different ecosystems (Note: land use data source: Center for Remote Sensing and Geographical Information System, Northeast Institute of Geography and Agroecology, Chinese Academy of Sciences).

As a first-class tributary of the Wusuli River, the Naoli River stems from Wanda Mountain, generally flowing from southwest to northeast. The total length of the Naoli River is about $596 \mathrm{~km}$. The majority of its tributaries originate from the right bank (the side of the Wanda Mountain), and the Qixing River is the main tributary distributed in the left bank. The average elevation of the watershed is $60 \mathrm{~m}$, which generally decreases from south to north and from west to east, and the plain mainly distributes in the middle of the basin and downstream reach of the river. In the basin, the low and flat terrain and widely distributed clayey soil layer, e.g., albic horizon within albic luvisol, facilitate the formulation of wetlands. This watershed has a frigid, temperate, continental monsoon climate, with an average annual temperature of $1.6^{\circ} \mathrm{C}$ [36]. The average July temperature is about $21.4^{\circ} \mathrm{C}$ and average January temperature is approximately $-21.6^{\circ} \mathrm{C}$ [35]. The mean annual precipitation is approximately $565 \mathrm{~mm}$, while the mean annual potential evaporation is about $542.4 \mathrm{~mm}$ [36].

The Naoli River watershed is an important wetlands distribution area, and approximately $23 \%$ of wetlands in the Sanjiang Plain are located in this basin. At present, there are two national nature reserves of wetlands within the basin, i.e., the Naolihe National Nature Reserve and Qixinghe National Nature Reserve. In aspects of economics, agriculture is the basic industry type within the basin, and rice, soybean, and maize are the three main types of crops being grown with the largest cultivated area and yields [37]. Coal mining is the important pillar industry of the region based on rich coal resources. In terms of population, there are about 2.4 million people living in the watershed, among which the amount of farm population is 1.1 million [38]. 


\subsection{Data Source}

The following datasets were acquired: land use/land cover of 2010 and soil type data obtained from Center for Remote Sensing and Geographical Information System, Northeast Institute of Geography and Agroecology, Chinese Academy of Sciences; slope data obtained from China's Geospatial Data Cloud [39]; DMSP/OLS nighttime light intensity data (2010), multi-level roads distribution data (2016), soil erosion grades data, Normalized Difference Vegetation Index (NDVI) data, and drying degree index data acquired from Resource and Environment Data Cloud Platform, Institute of Geographic Sciences and Natural Resources Research, Chinese Academy of Sciences [40]. Some town and farm distribution data were digitized from Google Earth and Farm Distribution Map of Heilongjiang Province, which was collected from Honghe Farm, Heilongjiang Province. Specifically speaking, land use/land cover data were used to rank regional ecological capital distribution based on its ecosystem services per unit area; data of DMSP/OLS nighttime light intensity, multi-level roads distribution, slope, NDVI, and drying degree index were ranked into four grades with ArcGIS "natural breaking" function and then processed further for regional ecological risk source intensity and vulnerability calculation; soil type data were used for the presentation of regional soil erodibility in accordance with its type. The auxiliary town and farm distribution data were adopted for mapping in the ArcGIS platform.

Among them, the DMSP/OLS nighttime light intensity data are a comprehensive proxy for spatial aggregation of human activities, including industrial agglomeration (secondary and tertiary industry), energy consumption, population density, and so forth [41]. Moreover, this dataset can also indicate the level and scale of the central place by light value and light area [41]; in other words, the higher the light value, the higher the level of the central place, and the larger the light area, the larger the scale of the central place, i.e., the higher the level of the central place. Thus, in this research, the DMSP/OLS nighttime light intensity data were used to describe and then analyze the distribution characteristics of multi-level central places (cities, counties, towns, farms, and farm branches).

The data processing platform is ArcGIS 10.2 version (ESRI, USA). The UTM zone 52N and WGS 84 datum were chosen as the project standard. All the original datasets were resampled to $1 \times 1 \mathrm{~km}$ grid cells so that the assessment framework could be realized in the ArcGIS platform.

\subsection{RERA Framework for the Naoli River Basin}

\subsubsection{Integrated Risk Assessment Model}

The regional ecological risk assessment function used in this study was as follows [42,43]:

$$
R=f(H) \times g(V) \times h(E)
$$

where $R$ is the value of the risk, $H$ is the risk source degree represented by human activities (manifested by nighttime light intensity grades, road density grades, soil erosion grades, and the NPS pollution stemming from paddy fields in this study; the former two indicators denote direct influence of human activities, whereas the latter two indicators represent indirect influence of human activities), $V$ is eco-environmental vulnerability of study area, and $E$ is the ecological capital of risk receptor. Based on the theory of Relative Risk Model (RRM) [44], all these three indicators $(H, V, E)$ were normalized to 4 grades using the "Natural Break" function (Jenks) in ArcGIS 10.2 before they were processed further. In the ranking process of true values of these three indexes, 1 denotes lowest risk source intensity, ecological capital value, and eco-environmental vulnerability degree of evaluation units, whereas 4 represent highest. The final risk value $(R)$ was also divided into 4 grades using same method, with 4 indicating the highest risk intensity and 1 the lowest.

The flow chart of wetland RERA in the Naoli River Watershed is shown in Figure 2. 


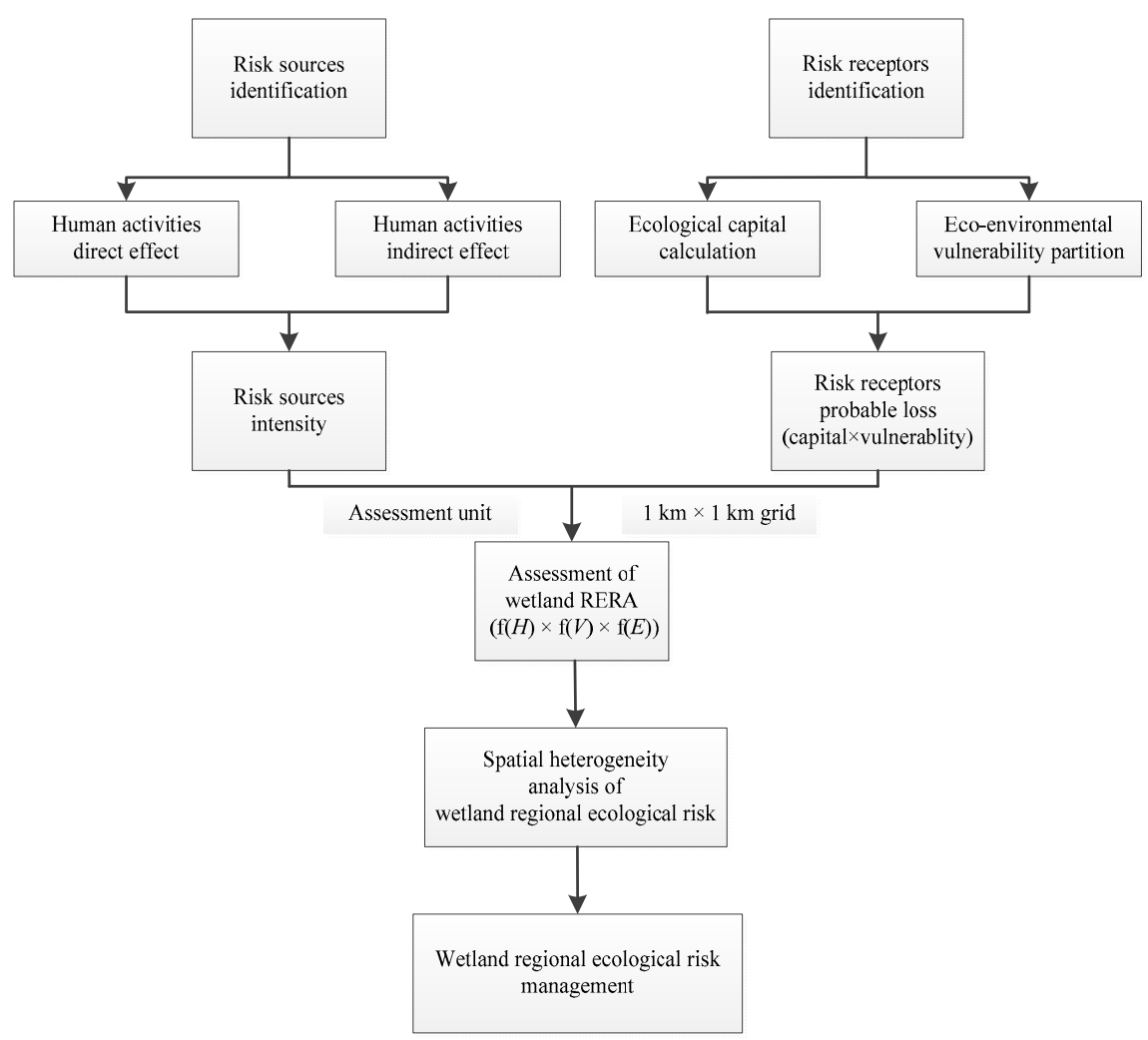

Figure 2. Flow chart of wetland regional ecological risk assessment (RERA) in the Naoli River Watershed.

The environmental vulnerability can influence the degree of human-caused damage on ecosystems. To evaluate the environmental vulnerability, four basic factors were taken into consideration in this study [42], i.e., slope (denoting the landform feature of the region), NDVI (Normalized Difference Vegetation Index, representing the vegetation cover discrepancy of the region), drying index (characterizing the regional climate vulnerability), and soil erodibility (manifesting the regional natural feature in terms of soil condition). Among them, the values of last index were assigned depending on soil types through giving a certain value to a specific soil type [45], and all the four indexes were ranking-standardized before being further processed.

In this study, $E$ is the ecological capital of risk receptor represented by ecosystem services value per unit area of all ecosystem types [13]. The ecosystems consist of dry cropland, paddy field, forest land, grassland, water body, construction land, barren land, and wetlands (Figure 1) in this study, and the services were divided into 9 types according to Xie et al. [46]: gas regulation, climate regulation, water conservation, soil formation and protection, waste treatment, biodiversity conservation, food production, raw material, and entertainment culture (Table 2). The final service value per unit area of every ecosystem was acquired through adding the values of single service type one by one.

Table 2. Ecosystem service value per unit area of different ecosystems in the Naoli River Watershed.

\begin{tabular}{ccccccccc}
\hline & \multicolumn{7}{c}{ Ecosystem Service Value/ $\left(\right.$ Yuan/hm $\mathbf{h}^{\mathbf{2}}$} \\
& $\begin{array}{c}\text { Dry } \\
\text { Cropland }\end{array}$ & $\begin{array}{c}\text { Paddy } \\
\text { Field }\end{array}$ & $\begin{array}{c}\text { Forest } \\
\text { Land }\end{array}$ & $\begin{array}{c}\text { Grass } \\
\text { Land }\end{array}$ & Wetland & $\begin{array}{c}\text { Water } \\
\text { Body }\end{array}$ & $\begin{array}{c}\text { Unused } \\
\text { Land }\end{array}$ & $\begin{array}{c}\text { Construction } \\
\text { Land }\end{array}$ \\
\hline Gas regulation & 442.4 & 1240.4 & 3097.0 & 707.9 & 1592.7 & 0 & 0 & 0 \\
Climate regulation & 787.5 & 2389.1 & 2389.1 & 796.4 & $15,130.9$ & 407 & 0 & 0 \\
Water conservation & 530.9 & 1891.0 & 2831.5 & 707.9 & $13,715.2$ & 18033.2 & 26.5 & 260.3 \\
$\begin{array}{c}\text { Soil formation } \\
\text { and protection }\end{array}$ & 1291.9 & 941.0 & 3450.9 & 1725.5 & 1513.1 & 8.8 & 17.7 & 86.8 \\
\hline
\end{tabular}


Table 2. Cont.

\begin{tabular}{ccccccccc}
\hline \multicolumn{10}{c}{ Ecosystem Service Value/ $\left(\mathbf{Y u a n} / \mathbf{h m}^{\mathbf{2}}\right)$} \\
\hline & $\begin{array}{c}\text { Dry } \\
\text { Cropland }\end{array}$ & $\begin{array}{c}\text { Paddy } \\
\text { Field }\end{array}$ & $\begin{array}{c}\text { Forest } \\
\text { Land }\end{array}$ & $\begin{array}{c}\text { Grass } \\
\text { Land }\end{array}$ & Wetland & $\begin{array}{c}\text { Water } \\
\text { Body }\end{array}$ & $\begin{array}{c}\text { Unused } \\
\text { Land }\end{array}$ & $\begin{array}{c}\text { Construction } \\
\text { Land }\end{array}$ \\
\hline Waste treatment & 1451.2 & 904.0 & 1159.2 & 1159.2 & $16,086.6$ & $16,086.6$ & 8.8 & 0 \\
Biodiversity & 628.2 & 1681.2 & 2884.6 & 964.5 & 2212.2 & 2203.3 & 300.8 & 0 \\
conservation & 884.9 & 1327.3 & 88.5 & 265.5 & 265.5 & 88.5 & 8.8 & 82.6 \\
Food production & 88.5 & 88.5 & 2300.6 & 44.2 & 61.9 & 8.8 & 0 & 0 \\
Raw material & 8.8 & 8.8 & 1132.6 & 35.4 & 4910.9 & 3840.2 & 8.8 & 82.6 \\
Entertainment culture & 6114.3 & $10,471.3$ & 19334 & 6406.5 & 55,489 & $40,676.4$ & 371.4 & 512.3 \\
Total & \multicolumn{7}{c}{ Adapted from [46-49]. }
\end{tabular}

\subsubsection{Risk Source Intensity Assessment Model}

The evaluation model of ecological risk source intensity was implemented with the following Equation [43]:

$$
H=\sum_{m=1}^{t}\left(w_{m} f_{m}\right)
$$

where $H$ represents the ecological risk source intensity, $f_{m}$ represents the risk source factors that were normalized first (4 grades with 1 indicating low-risk source intensity, 2 medium-risk source intensity, 3 high-risk source intensity, and 4 very high-risk source intensity), $w_{m}$ represents the weights of $f_{m}, t$ is the number of risk source factors, and $0<m<t+1$. In this study, the weights of DMSP/OLS nighttime light intensity, road density, soil erosion, and the NPS pollution denoted by paddy fields were assigned as $0.3,0.3,0.2,0.2$, respectively, according to land use intensity they indicate. (Concretely speaking, the former two proxies denote construction land with high land use intensity, whereas the last two represent cropland and forestland with relatively low land use intensity. Based on the land use degree research, the values of land use intensity of construction land, cropland, forest land, and unused land, are $4,3,2$, and 1 , respectively, so the weights of the four risk source intensity indicators of this study were assigned as $0.3,0.3,0.2$, and 0.2 , respectively [43,50].

Among risk source factors, the normalized ranking-length of roads with multi-levels were comprehensively calculated using the "Zonal Statistics" function $(10 \times 10 \mathrm{~km}$ grids were used as basic statistic units) in ArcGIS 10.2 and weights of 4 (highway and railway), 3 (national road), 2 (provincial road and municipal road), and 1 (county road and town road). The final road density value was divided into four levels using the "Natural Break" function in ArcGIS 10.2, with 4 indicating the highest road density grade and 1 the lowest one.

Considering the severe impact of groundwater-fed paddy field irrigation on regional groundwater resources and environment (which can cause severe consequences such as groundwater resources depletion, groundwater level lowering, difficulty to withdraw groundwater, and land-surface subsidence, and so forth), the intensity of paddy fields usage was assigned 3 in this study (compared to the 4-level partition of severity of the other three risk sources, where 4 indicates the most serious human effect) [51]. According to the availability of data and workload needed, the NPS pollution within paddy fields was not actually modelled but was assigned artificially based on paddy fields distribution. The related research will be finished in the future.

\subsubsection{Environment Vulnerability Assessment Model}

Eco-environmental vulnerability was evaluated based on the following equation [42,43]:

$$
V=\sum_{n=1}^{l}\left(w_{n} f_{n}\right)
$$


where $V$ represents the eco-environmental vulnerability, $f_{n}$ represents the vulnerability factors that were normalized first (4 grades with 1 denoting low vulnerability, 2 medium vulnerability, 3 high vulnerability, and 4 very high vulnerability), $w_{n}$ represents the weights of $f_{n}, l$ is the number of vulnerability factors, and $0<n<l+1$.

Generally speaking, the vulnerability degree increases with higher slope, drying index, and soil erodibility value, and lower vegetation coverage percentage, and vice versa [42]. Therefore, the division of regional vulnerability grades of these factors in the Naoli River Watershed was realized as shown in Table 3. The weights of slope, NDVI, drying degree index, and soil erodibility were assigned as $0.3,0.3,0.2$, and 0.2 , respectively, according to their relative importance [42,43]. Moreover, because wetland is a typical ecotone between terrestrial and aquatic ecosystems with a higher vulnerability level [52], the normalized vulnerability value of the wetland's distribution area was lastly added by 1 to obtain a comprehensive understanding of the effect of eco-environmental vulnerability on final risk assessment outcome.

Table 3. Indices used for eco-environmental vulnerability assessment in the Naoli River Basin.

\begin{tabular}{|c|c|c|c|c|c|}
\hline \multirow{2}{*}{ Factors } & \multicolumn{4}{|c|}{ Grades Assigned } & \multirow{2}{*}{ Weight } \\
\hline & 1 & 2 & 3 & 4 & \\
\hline Slope $\left(^{\circ}\right)$ & $<2.50$ & $2.50-6.88$ & $6.88-12.56$ & $>12.56$ & 0.3 \\
\hline Vegetation Coverage (\%) & $>87.18$ & $83.52-87.18$ & $75.54-83.52$ & $<75.54$ & 0.3 \\
\hline Drought Index & $<0.96$ & $0.96-0.99$ & $0.99-1.03$ & $>1.03$ & 0.2 \\
\hline Soil Erodibility (K value) & $<0.26$ & $0.26-0.32$ & $0.32-0.38$ & $>0.38$ & 0.2 \\
\hline Revised & \multicolumn{5}{|c|}{ Vulnerable ecotone between land and water body $(\mathrm{Y}, \mathrm{N}) \mathrm{Y}=1, \mathrm{~N}=0$} \\
\hline
\end{tabular}

\subsubsection{Ecological Capital Assessment Model}

In this paper, the final service value per unit area of every ecosystem was acquired through adding the values of single service types one by one. The total ecosystem service value per unit area of all ecosystems was normalized by the equal distance division method. Based on the calculated results, the final integrated ecological capitals per unit area of all ecosystems were divided into 4'grades, i.e., [371.4, 14,150.8], [14,150.8, 27,930.2], [27,930.2, 41,709.6], [41,709.6, 55,489]. Eventually, the final grouping was as follows: grade 1 ([371.4, 14,150.8]) including dry cropland, paddy field, grassland, unused land, and construction land; grade 2 ([14,150.8, 27,930.2]) denoting forest land; grade 3 ([27930.2, $41709.6])$ indicating water body; and grade 4 ([41,709.6, 55,489]) referring to wetland.

\section{Results}

\subsection{Intensity of Risk Source in the Naoli River Watershed}

\section{Ecological Risk Source Intensity}

As shown in Figure 3a, the DMSP/OLS nighttime light data matched the distribution of multi-level central places well, with a large area of grade 4 and grade 3 indicating distribution of high-level central places, such as county seat, district, and area administration bureau of farms located in. On the other hand, the relatively small area of grade 4 and grade 3 indicates the distribution of low-level central places, e.g., farms, towns, and farm branches. The normalized ranking density of multi-level roads displayed a ring-shape distribution feature around the center of the Naoli River Basin, which is in line with the distribution of roads with high levels (e.g., highway, railway, and provincial road) (Figure 3b). The high and very high grades of soil erosion (grade 3 and grade 4 ) were mainly distributed in Qitaihe region, surrounding the Hongwei Town, whereas the medium-risk grade of soil erosion was mainly distributed in other parts southwest of the study area (Figure 3c). The farm and paddy fields distribution features are shown in Figure 4a,b, respectively. From these two figures, we could see that the paddy fields were mainly distributed in state-owned farms, as a result of successive large-scale 
reclamation of wetlands after the founding of the People's Republic of China. As their maintenance needs more investment and intensive field management, the state-owned farms, with the institutional merits of centralized management, could meet these demands of rice cultivation.

(a) Nighttime light intensity

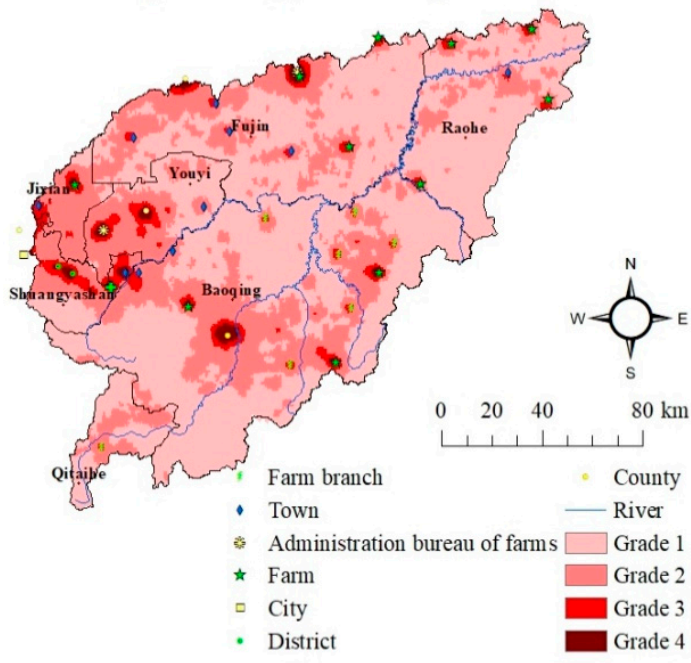

(b) Road density

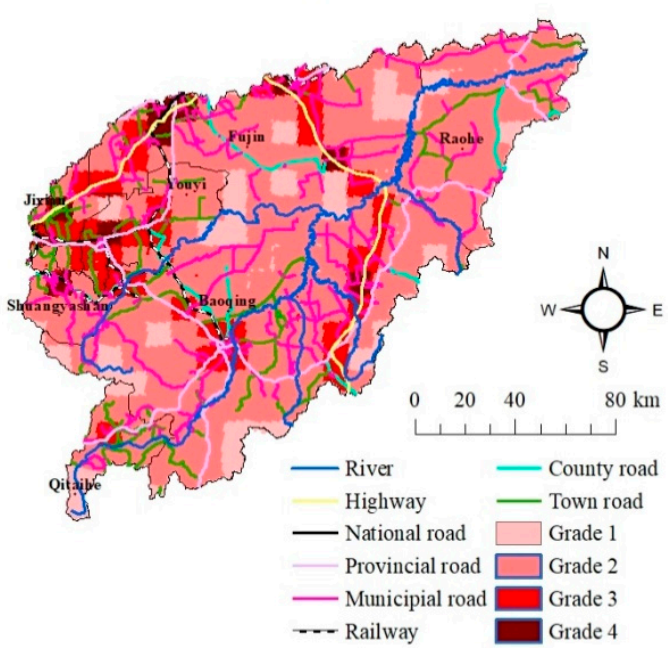

(c) Soil erosion

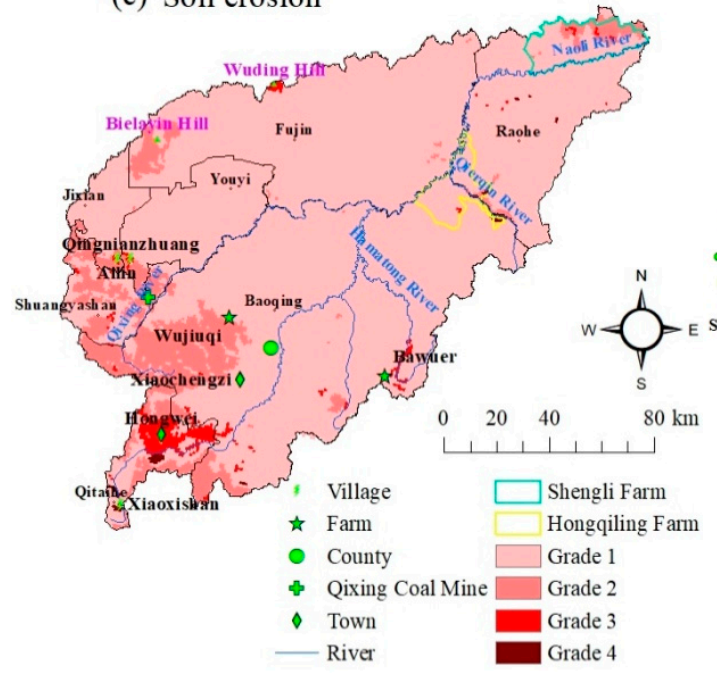

(d) Integrated risk source intensity

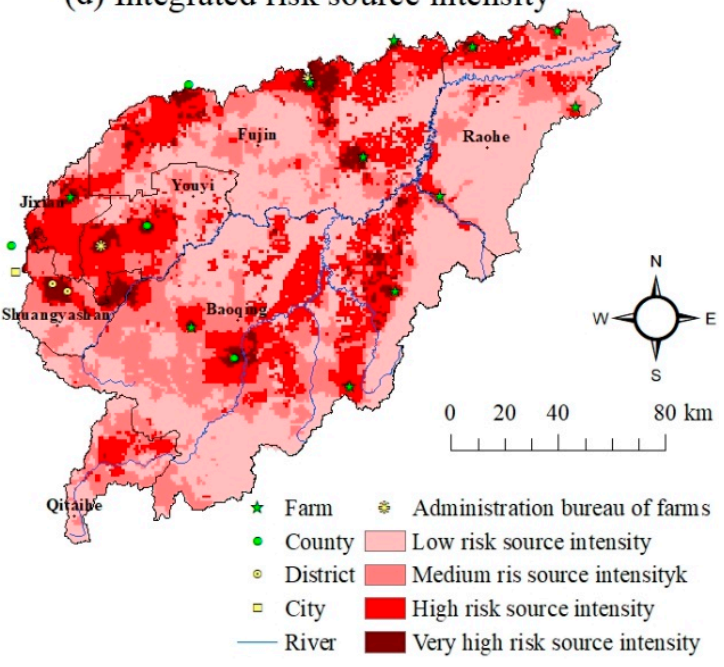

Figure 3. Grades of risk source intensity in the Naoli River Basin with (a) nighttime light intensity grades; (b) road normalized ranking density; (c) soil erosion grades; and (d) grades of integrated risk source intensity.

Based on Formula 2, the final risk source intensity of the Naoli River Watershed was weighted, overloaded, and then divided into 4 grades (Figure 3d). As shown in Figure 3d, high- and very high-risk source intensity areas displayed a ring-shape distribution basically, which reflected the influence of the regional pole-axis system (central places and roads with high levels). Overall, the highest level of risk source intensity (grade 4) was matched well with the high-level central places, e.g., district, county seat, and administration bureau of farms. Moreover, the distribution of high- and very high-risk source intensity areas also reflected the effect of soil erosion in Qitaihe region (upstream of the Naoli River) and paddy fields in the middle and downstream of the Naoli River. In terms of proportion, the low, medium, high, and very high grade of risk source intensity areas accounted for $45.3 \%, 26.5 \%, 24.1 \%$, and $4.1 \%$ of the study area, respectively. 
(a) Farm distribution

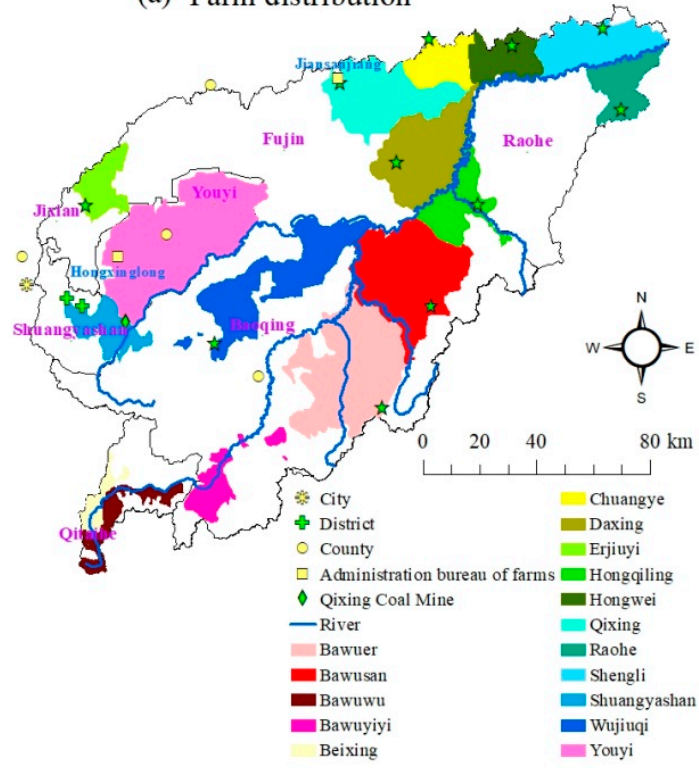

(b) Paddy fields distribution

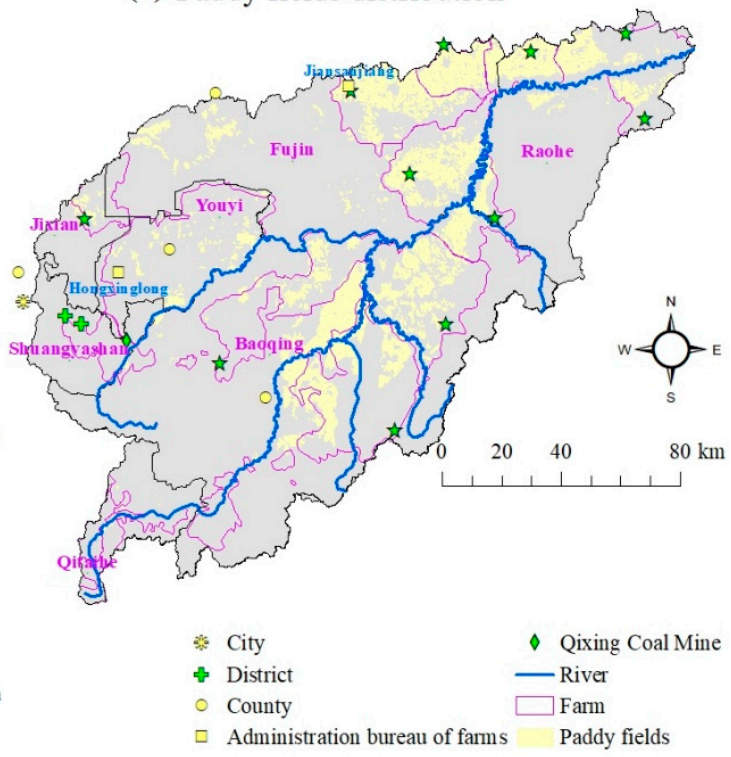

Figure 4. Distribution of farms (a) and paddy fields (b) in the Naoli River Basin.

\subsection{Characteristics of Risk Receptor Indices in the Naoli River Watershed}

\subsubsection{Ecological Fragility Distribution}

As shown in Figure 5a, the central places with high levels were almost all situated in the flat region (grade 1). The great slope area was mainly distributed southwest and southeast of the Naoli River Basin, which is in line with the distribution of forest land within the mountainous area. Some farms (e.g., Bawuer, Bawusan, Wujiuqi, Hongqiling, Raohe, and Shengli) were located at the edge between mountain and plain, reflecting the occurrence order of regional human activities, which spread from the hilly and drying area to low and wet marshy plain. The high and very high levels of vegetation coverage vulnerability (grade 3 and grade 4) were mainly covered by water body, county seat, and area administration bureau of farms located in, whereas the medium level of vegetation coverage vulnerability was matched well with the distribution of wetlands (Figure 5b). The severe drying area was mainly distributed in Baoqing County and displayed a two-horizon circle structure; the county seat of Baoqing was almost in the center of the severe drying circle (Figure $5 \mathrm{c}$ ). In terms of soil erodibility, the low, flat plain area adjacent to Naoli River manifested a low level of soil erodibility, whereas the upstream and southeast hilly region was in the high-level groups of soil erodibility (Figure 5d).

Based on Formula 3 and ecotone (wetlands) distribution data, the final eco-environmental vulnerability of the Naoli River Watershed was calculated and is shown in Figure 6a. From Figure 6a, we could see that overall, the wetlands had the highest vulnerability level. For example, the wetland nature reserves Sanhuanpao, Changlindao, Qixinghe, Yanwodao, Dongsheng, Naolihe, and Dajiahe, were all located in the scope of very high vulnerability grade. Besides wetlands, the high and very high grades of vulnerability were mainly distributed to the south of the Naoli-Qixing River, which reflected the influence of regional slope and weather drying situation. In terms of proportion, the low, medium, high, and very high grades of vulnerability areas accounted for $55.8 \%, 24.5 \%, 12.8 \%$, and $7.0 \%$ of the study area, respectively. 
(a) Slope

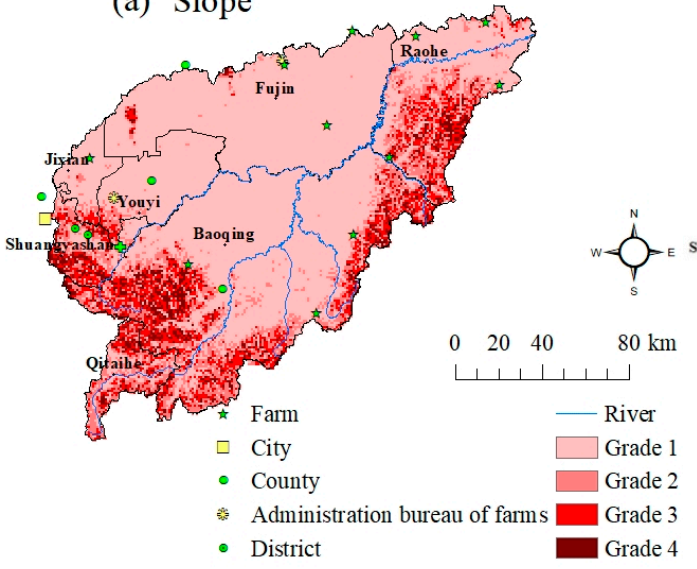

(c) Drying index

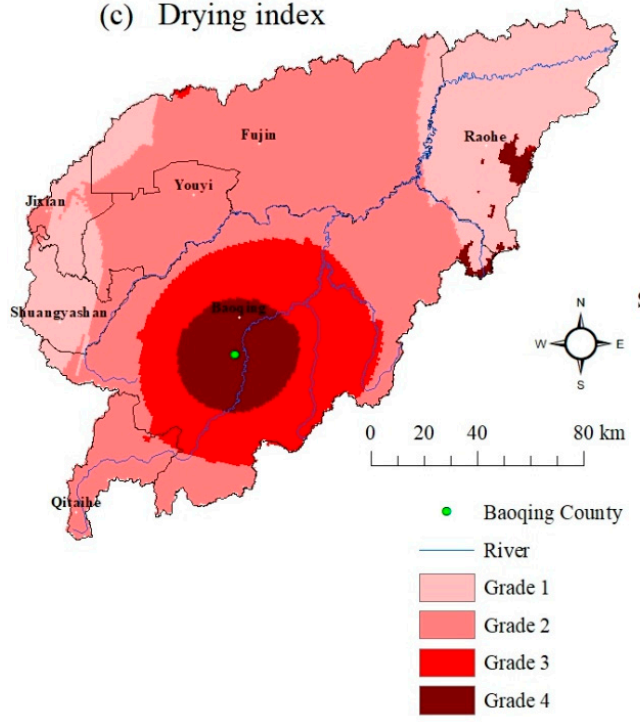

(b) NDVI

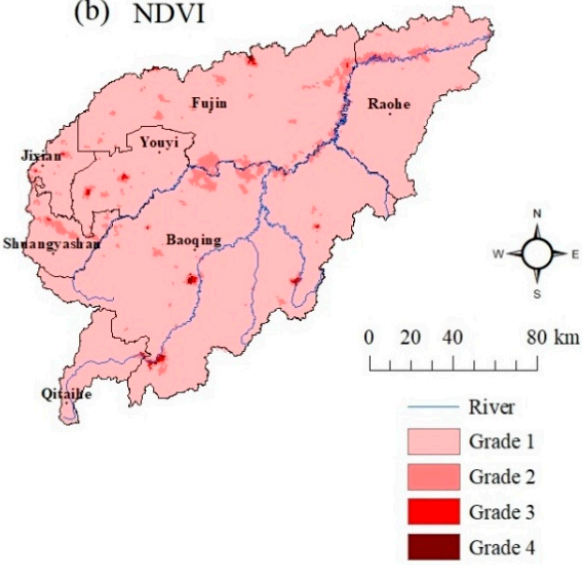

(d) Soil erodibility

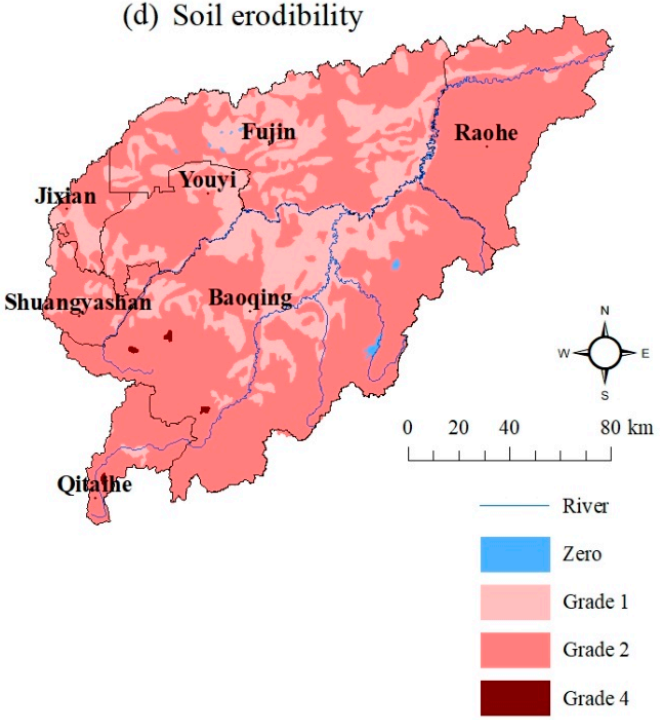

Figure 5. Grades of vulnerability factors in the Naoli River Basin with (a) slope grades; (b) normalized difference vegetation index (NDVI; representing vegetation cover) vulnerability grades; (c) grades of drying index; and (d) soil erodibility grades.

(a) Vulnerability grades

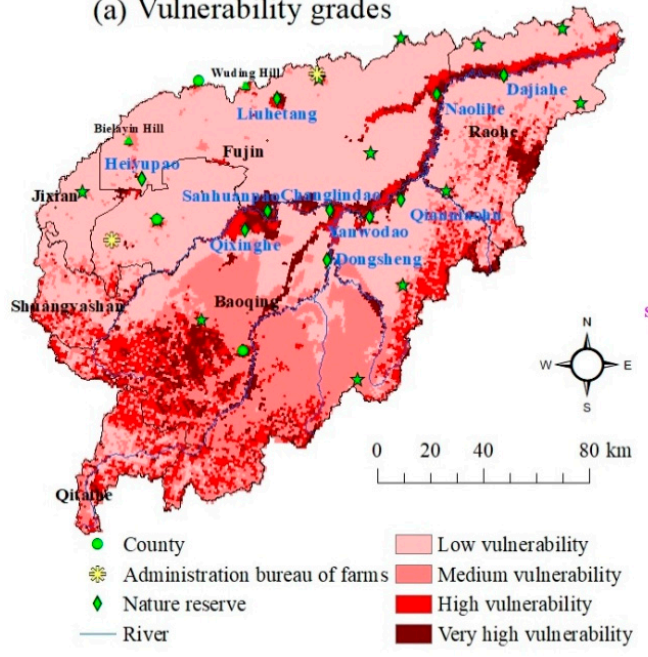

(b) Ecological capital grades

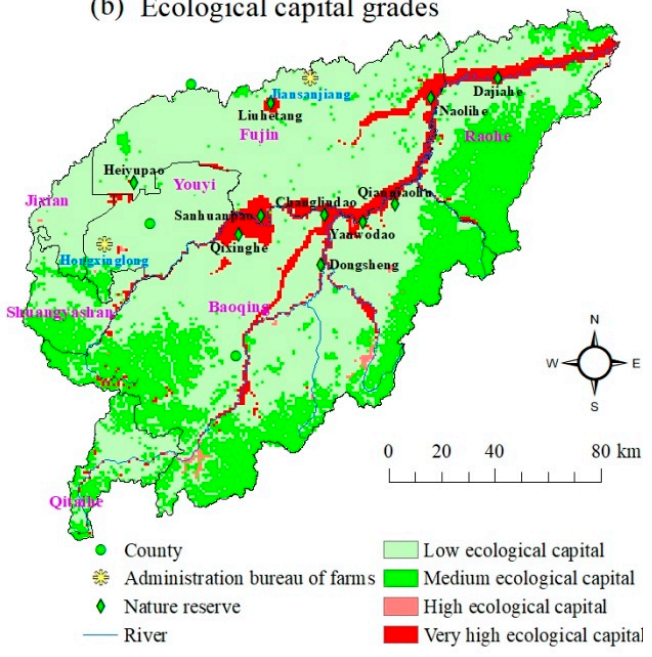

Figure 6. Grades of (a) vulnerability and (b) ecological capital in the Naoli River Watershed. 


\subsubsection{Ecological Capital Distribution}

The ecological capital rankings of all ecosystems were calculated and are shown in Figure $6 \mathrm{~b}$. As shown in Figure 6b, the region of very high level of ecological capital reflected the distribution of wetlands, whereas the high-level region of ecological capital reflected the distribution of water body. The medium grade of ecological capital area displayed the range of forest land, while the low grade of ecological capital area included all the rest of the land cover types, e.g., dry cropland, paddy field, construction land, grassland, and barren land. In terms of percentage, the low, medium, high, and very high grades of ecological capital areas accounted for $66.5 \%, 26.2 \%, 0.5 \%$, and $6.9 \%$ of the study area, respectively.

\subsection{Integrated Ecological Risk Degree in the Naoli River Watershed}

Based on Formula 1, the final risk grades of the study area were calculated and are shown in Figure 7. As shown in Figure 7, owing to their high ecological capital value per unit area and vulnerability level, the wetlands had higher final risk grade. For example, the wetland nature reserves Sanhuanpao, Changlindao, Qixinghe, Yanwodao, Dongsheng, Qianniaohu, Naolihe, and Dajiahe were all located in the scope of the high-risk grade. Moreover, the very high-risk grade area mainly consisted of riparian wetlands, e.g., the riparian wetlands between Hongshan Village and Guoyingyuliangzi (the Naoli River). Apart from wetlands, the high-risk grade area was mainly distributed in the southwest mountainous region. The central places with high levels were also distributed in the final high-risk grade area, such as Baoqing County Seat; Youyi County Seat; administration bureau of farms in Hongxinglong and Jiansanjiang; farm towns of Bawuer, Bawusan, and Hongqiling, etc. In terms of proportion, the low, medium, high, and very high-risk grade areas accounted for $72.0 \%, 16.8 \%, 10.1 \%$, and $1.1 \%$ of the study area, respectively.

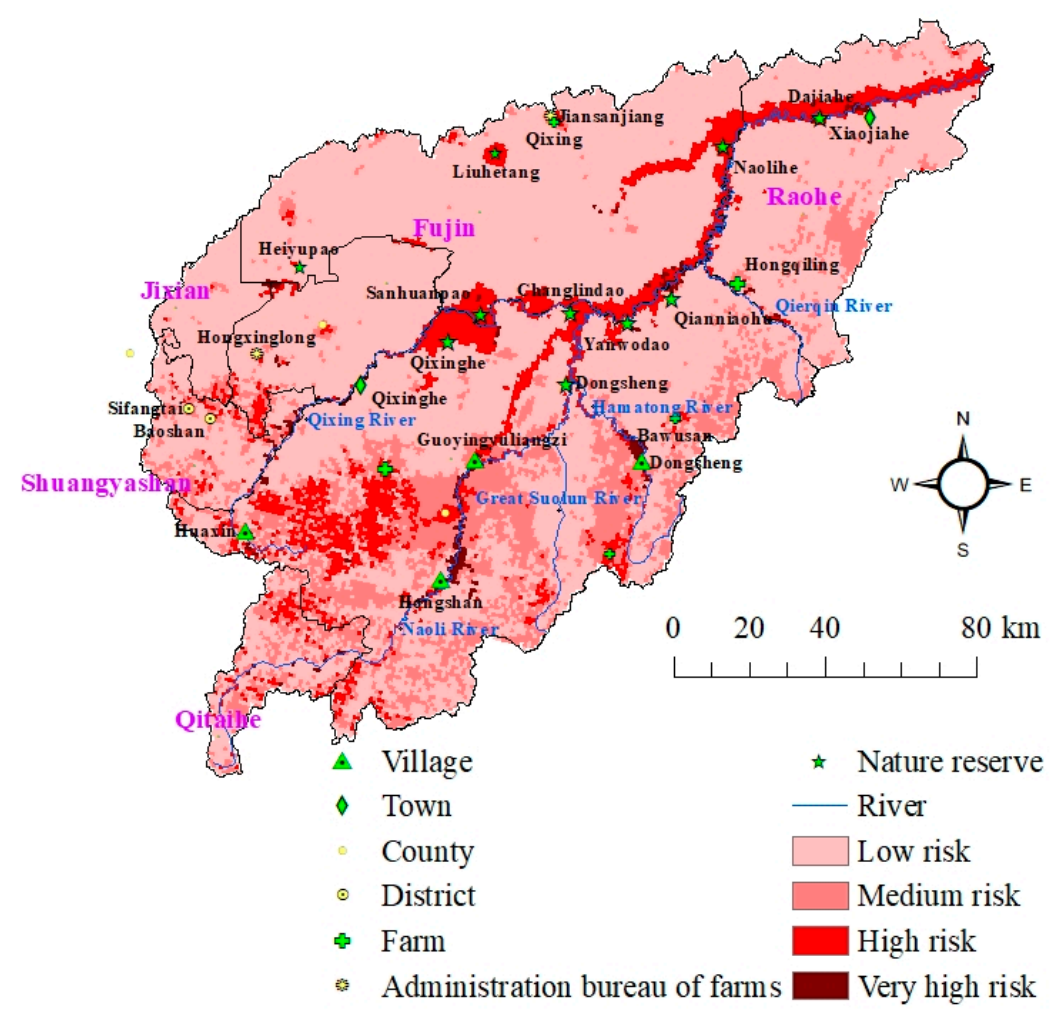

Figure 7. Distribution of final risk grades in the Naoli River Watershed. 


\section{Discussion}

From the final risk grades distribution pattern (Figure 7), we can see that wetlands and southwest mountainous area have the higher final risk level. On account of the theme of this research, the following part of the paper focuses on the discussion of wetland risk prevention and management guidelines for their future protection.

\subsection{Spatial Relationship between Regional Pole-Axis System and Wetlands in the Naoli River Watershed}

The spatial adjacency between the regional pole-axis system (multi-level central places and roads) and wetlands is displayed in Figure 8. Normally, farms denote recent and relatively mild human activities within the basin because they were almost reclaimed from marshland after the founding of the People's Republic of China, whereas the cities and county seats represent the historically long-term and severe human activities, which generally happen in hilly non-marsh areas within the basin. Thus, as shown in Figure 8, the central places with high levels (district, county, and area administration bureau of farms located in) were almost distributed in the west part of the region, whereas the farms were mainly located in the east part of the basin, and this difference pattern reflects the spreading order of human settlements and reclamation from west to east and from hillside to marshy plains in the Sanjiang Plain. We could also see that high-level central places were passed through by high-level roads generally, like railways, highways, national roads, and provincial roads, hoping to promote human, material, and financial resources communication between different regions. Of course, the central places with low levels were also passed by low-level roads, such as county roads and town roads. From Figure 8 we could see that the roads with high levels, e.g., railways, highways, and provincial roads, were mainly distributed around the center of the basin, where wetlands are concentrated. These high-level roads connected regionally important central places, e.g., county seat, administration bureau of farms in the west part, and farms in the east part of the basin.

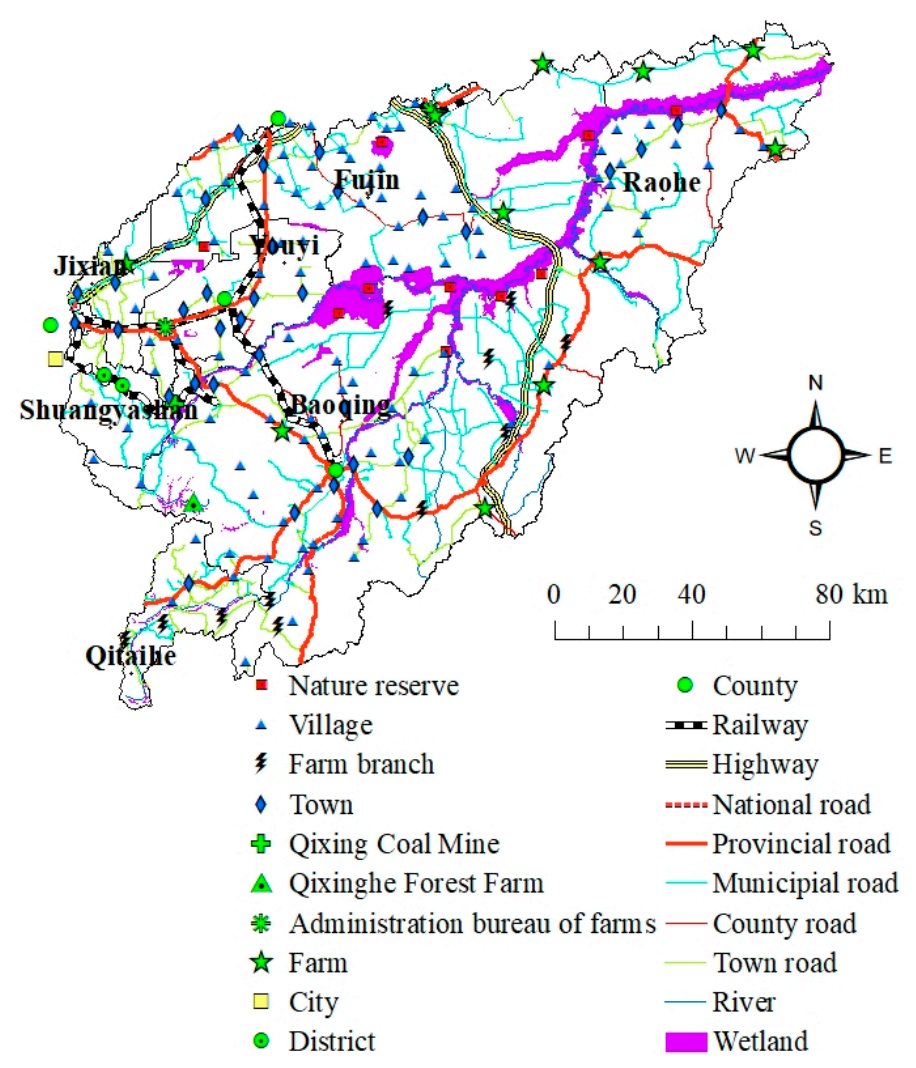

Figure 8. Spatial position relationship between regional pole-axis system and wetlands in the Naoli River Watershed. 
In the Naoli River Watershed, central places with high levels (county seat, area administration bureau of farms located in, and district) were far away from wetlands generally, while low-level central places (farms, farm branches, and towns) were normally located near the edge of them. Consequently, the central places with high levels mainly affected wetlands through economic and policy approaches (e.g., reclamation and project construction), and the low-level central places influenced them by acquiring natural resources directly, such as fresh water, fish, bird eggs, reeds, and landscape and spaces (for enjoyment and recreation), etc. Overall, the low-level central places could affect wetlands more often daily, but the central places with high levels could impact them more severely by chance, so the effect of human activities coming from nearby low-level central places (e.g., villages, towns, farm branches, and farms) on wetlands should be emphasized in daily management, whereas the proposal and implementation of wetland-related development policy and engineering projects in high-level central places must be cautious.

Relatively, the high-level roads seldom went through wetlands, and it was only in the south edge of Daxing Farm and the north edge of Xiaojiahe Town that the wetlands passed through by Jian-Ji Highway (from Jiansanjiang administration bureau of farms to Jixi City) and 210 provincial road (from Fuyuan County to Raohe County), respectively. Contrarily, many municipal roads, county roads, and town roads had access to low-level central places at the edge of wetlands, such as farm branches and towns and even small villages. Thus, generally speaking, the low-level roads have more chance to influence the health of wetlands because they are normally distributed near the edge of wetlands, such as the situation happening on the east edge of Daxing Farm (049 town road (Daxing Farm-Xifeng Town section) where wetland reclamation and digging and grazing were serious. Accordingly, management of influences coming from multi-level roads, especial low-level roads, must be treated seriously in daily management of wetlands in the future.

As for policy implication of wetland protection in the future, the following management policies could be acquired: the strictest spatial governance of important wetlands, such as multi-level nature reserves, which needs to limit their accessibility; nature reserve establishment when necessary, e.g., in the "gap" region, which is important with high biodiversity protection value and others not covered by current wetland nature reserves; village/town/farm planning and adjustment through increasing their distance to nearby wetlands on account of their direct impact on wetlands, such as reclamation, extra usage of biological resources, and so on; road distribution planning and adjustment considering their accessibility to wetlands and consequent influences.

\subsection{Tradeoff and Synergy between Wetlands and Other Ecosystems in the Naoli River Watershed}

The spatial distribution of soil erosion grades, paddy fields, and wetlands is shown in Figure 9. The material output (e.g., sand, nitrogen compounds, and phosphorus compounds) from upstream ecosystems, especially forest land, dry cropland, and paddy fields, could affect the structure and function of wetlands. For example, owing to silt deposition, the Carex Community was replaced by the Hibiscus Community gradually in the Naoli River riparian wetlands in Xiaojiahe Town and Changlindao Nature Reserve recently [53]. This situation was maybe related to the effect of sand deposition on germination rate of the seed bank in the wetlands [32]. The excessive input of nitrogen and phosphorous from soil erosion within the forestland and dry cropland area and the NPS pollution from paddy fields could influence the stability of the carbon bank of wetlands through promoting their greenhouse gas emission [31,33]. At the same time as soil erosion, the damage to the forest upstream could also impact the water conservation function of forest land (owing to it developing a thinner soil layer and the loss of the litter layer within this ecosystem), which is an important replenishment source of water to downstream wetlands [54]. Moreover, the ditch construction within surrounding paddy fields could cut down the scope and amount of runoff of wetlands, which can also cause drought damage to downstream wetlands in years with insufficient precipitation. Accordingly, the unreasonable human activities within non-wetland ecosystems could affect the health of wetlands and increase their 
risk level. For this reason, the rational and sustainable use of forest land, dry cropland, and paddy fields is important for wetlands protection.

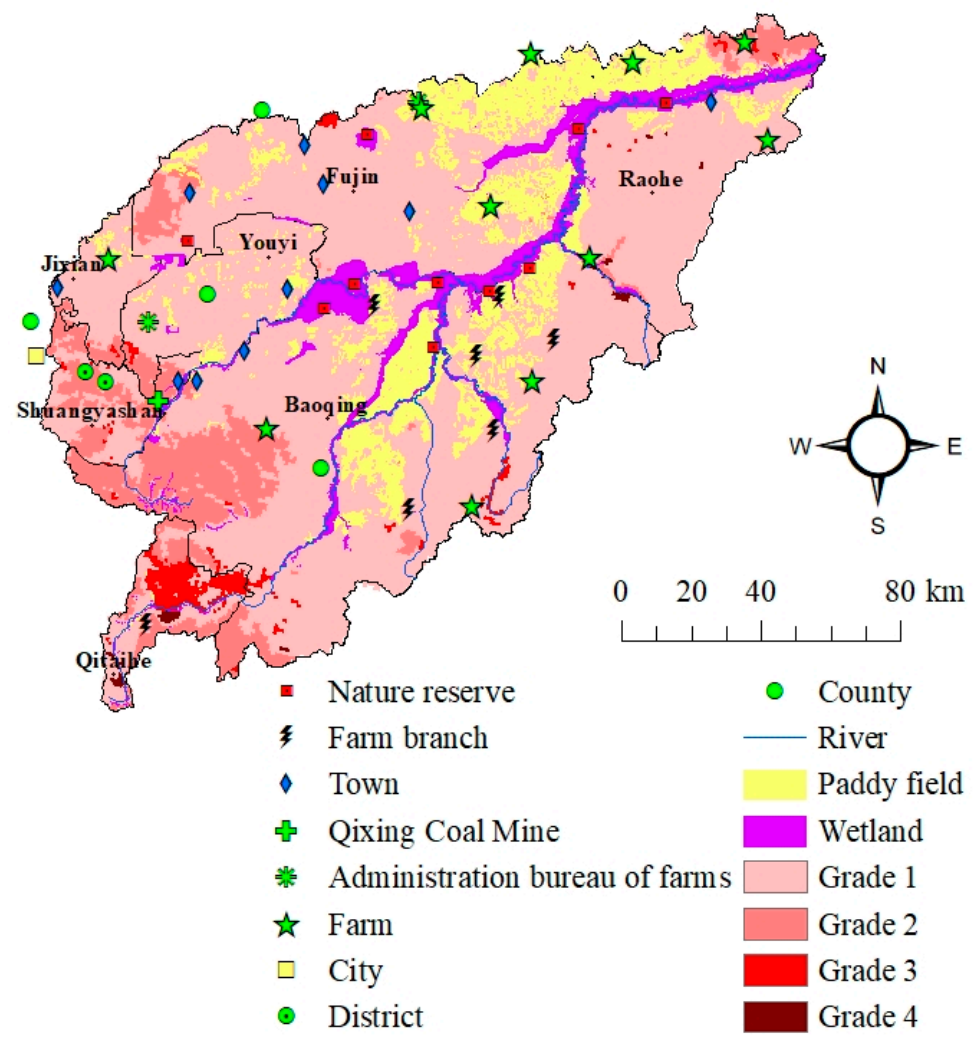

Figure 9. Distribution of soil erosion grades and paddy fields in the Naoli River Watershed.

Taking the integrated management of wetlands and non-wetland ecosystems into consideration, the management of human activities within the non-wetland region involves two concepts, i.e., tradeoff and synergy [43]. Tradeoff means the restriction of the main function of an ecosystem can stimulate the health improvement of the other [55], like the relationship between cropland (dry cropland and paddy fields) and wetlands. As the main functions of cropland and wetlands are grain production and ecosystem services, respectively, the reasonable regulation of production function of cropland (otherwise causing soil erosion and NPS pollution and so on) could reduce the output amount of sand and compounds of nitrogen and phosphorus and then promote the health of downstream wetlands owing to reduction of input of these materials. Contrarily, synergy means the protection and maintenance of the main function of an ecosystem can stimulate the health improvement of the other [55], like the relationship between forest land and wetlands. Owing to the fact that the main functions of these two ecosystems are ecosystem services, the protection of water conservation and soil maintenance function of forest land could also reduce the output amount of sand and compounds of nitrogen and phosphorus, and augment the runoff yielding capacity of the watershed. Correspondingly, the downstream wetlands health condition would be improved owing to reduction of input of these materials and more freshwater input. Therefore, the comprehensive management of wetlands and non-wetland ecosystems could maximize overall benefits and minimize the risk grade of wetlands ultimately.

As required for tradeoff, the amount of fertilizer used in cropland area must be controlled strictly to reduce the output of nitrogen and phosphorous compounds, which could ultimately be transported into downstream wetlands. In other words, the rational application of fertilizer policy must be acquired. The ecological transformation of ditches within the paddy fields region could also lessen the input of nitrogen and phosphorous of wetlands by soil adsorption, plant absorption, and microbiological 
assimilation [34,56,57]. Moreover, the Grain for Green policy, Equal Height Farming, and Terrace Construction Strategy must be adopted within the steep slope area in order to control the soil erosion problem of this basin. Considering synergy between forest land and wetlands, the restricted logging policy must be taken into account to maintain canopy density and litter and soil layer thickness of the forest, which is good for protection of water and soil conservation function of forest land. All these approaches would reduce risk level of wetlands effectively in the Naoli River Watershed on the whole.

\section{Conclusions}

In this study, a wetland RERA framework was established to analyze the spatial heterogeneity of risk source intensity, ecological capital, environmental vulnerability, and final risk grades in the Naoli River Watershed, one wetlands-concentrated basin of the Sanjiang Plain. Based on the division of direct and indirect influences of human activities, which could affect the structure and function of wetlands, the regional pole-axis system (central places and roads system) was selected as a proxy of direct effect of human activities on wetlands, whereas the soil erosion and the NPS pollution were selected as proxies of indirect effect of human activities on wetlands. The results indicated that: (1) the DMSP/OLS nighttime light intensity data could fit the distribution of multi-level central places very well, and it was reasonable to use this dataset to analyze the spatial grades of multi-level central places in the Naoli River Watershed; (2) owing to their high ecological capital value per unit area and vulnerability level, the wetlands had the highest risk grade, and so did central places with high levels, such as county seat; (3) in terms of proportion, high- and very high-risk grades accounted for $11.2 \%$ of the whole region totally, and the rest of the area ranged from low- to medium-risk grade. As for wetlands risk prevention, the spatial adjacency situation between the regional pole-axis system (multi-level central places and roads) and wetlands must be considered particularly; meanwhile, the tradeoff and synergy management between wetlands and other ecosystems should be emphasized. By adopting these management viewpoints, the risk level of wetlands could be reduced effectively on the level of the whole basin in the future.

Author Contributions: H.W. collected the datasets used in this research, designed the structure of the manuscript, and wrote the draft of the manuscript. K.S. revised the draft and wrote the second draft of the manuscript and provided a lot of advice for figure homogenization. C.S. afforded funding support for this research and gave some comments on this manuscript. Finally, the manuscript was revised by H.W. in accordance with the opinions of referees. All authors have read and agreed to the published version of the manuscript.

Funding: This research was funded by National Key Basic Research Program of China grant number [2016YFA0602303, 2016YFA0602304] and The APC was funded by launching funds of Jiujiang University for doctors [8691409].

Acknowledgments: This research was financially supported by the National Key Basic Research Program of China (2016YFA0602303, 2016YFA0602304) and the authors kindly acknowledge the support.

Conflicts of Interest: The authors declare no conflict of interest.

\section{References}

1. Fu, Z.Y.; Xu, X.G.; Lin, H.P.; Wang, X.L. Regional ecological risk assessment of the Liaohe River Delta wetlands. Acta Ecolo. Sinica 2001, 21, 365-373.

2. Xu, X.G.; Lin, H.P.; Fu, Z.Y.; Bu, R.C. Regional ecological risk assessment of wetland in the Huanghe River Delta. Acta Sci. Nat. Univ. Pekin. 2001, 37, 111-120.

3. Xu, X.; Lin, H.; Fu, Z. Probe into the method of regional ecological risk assessment-a case study of wetland in the Yellow River Delta in China. J. Environ. Manag. 2004, 70, 253-262. [CrossRef] [PubMed]

4. Wang, H.; Song, C.C.; Song, Y.Y. Scale-dependence of ecological risk assessment and scheme formulation for regional ecological risk assessment of wetlands in Sanjiang Plain. Wetland Sci. 2018, 16, 106-113.

5. Malekmohammadi, B.; Blouchi, L.R. Ecological risk assessment of wetland ecosystems using Multi Criteria Decision Making and Geographic Information System. Ecol. Indic. 2014, 41, 133-144. [CrossRef]

6. Patton, D.E. The U.S. environmental protection agency's framework for ecological risk assessment. Hum. Ecol. Risk Assess. Int. J. 1995, 1, 348-356. [CrossRef] 
7. Peng, T.; Li, J.; Gong, H.; Pu, R.; Li, J.; Shao, S.; Shi, Z.; Feng, X.; Wang, L.; Liu, R. Research on Land Use Changes and Ecological Risk Assessment in Yongjiang River Basin in Zhejiang Province, China. Sustainability 2019, 11, 2817.

8. Lu, Y.; Qin, F.; Chang, Z.; Bao, S. Regional Ecological Risk Assessment in the Huai River Watershed during 2010-2015. Sustainability 2017, 9, 2231. [CrossRef]

9. U.S. Environmental Protection Agency. Guidelines for Ecological Risk Assessment; Risk Assessment Forum: Washington, DC, USA, 1998; pp. 4-5.

10. Landis, W.; Wiegers, J.A. Design considerations and a suggested approach for regional and comparative ecological risk assessment. Hum. Ecol. Risk Assess. Int. J. 1997, 3, 287-297. [CrossRef]

11. Moraes, R.; Molander, S. A Procedure for Ecological Tiered Assessment of Risks (PETAR). Hum. Ecol. Risk Assess. Int. J. 2004, 10, 349-371. [CrossRef]

12. Peng, J.; Zong, M.; Hu, Y.; Liu, Y.; Wu, J. Assessing Landscape Ecological Risk in a Mining City: A Case Study in Liaoyuan City, China. Sustainability 2015, 7, 8312-8334. [CrossRef]

13. Costanza, R.; D'Arge, R.; De Groot, R.; Farber, S.; Grasso, M.; Hannon, B.; Limburg, K.; Naeem, S.; O’Neill, R.V.; Paruelo, J.; et al. The value of the world's ecosystem services and natural capital. Nature 1997, 387, 253-260. [CrossRef]

14. Xu, S.; Liu, X.; Li, X.; Tian, C. Soil organic carbon changes following wetland cultivation: A global meta-analysis. Geoderma 2019, 347, 49-58. [CrossRef]

15. Mitsch, W.; Bernal, B.; Nahlik, A.; Mander, Ü.; Zhang, L.; Anderson, C.J.; Jørgensen, S.E.; Brix, H. Wetlands, carbon, and climate change. Landsc. Ecol. 2012, 28, 583-597. [CrossRef]

16. Chen, H.; Zhang, W.; Gao, H.; Zhang, W. Climate Change and Anthropogenic Impacts on Wetland and Agriculture in the Songnen and Sanjiang Plain, Northeast China. Remote. Sens. 2018, 10, 356. [CrossRef]

17. Liu, Y.C.; Liu, Y.X.; Li, J.L.; Lu, W.Y.; Wei, X.L.; Sun, C. Evolution of landscape ecological risk at the optical scale: A case study of the open coastal wetlands in Jiangsu, China. Int. J. Environ. Res. Public Health. 2018, 15, 1691. [CrossRef]

18. Jiang, W.; Lv, J.; Wang, C.; Chen, Z.; Liu, Y. Marsh wetland degradation risk assessment and change analysis: A case study in the Zoige Plateau, China. Ecol. Indic. 2017, 82, 316-326. [CrossRef]

19. Wanda, E.; Mamba, B.B.; Msagati, T.A.M.; Msilimba, G. Determination of the health of Lunyangwa wetland using Wetland Classification and Risk Assessment Index. Phys. Chem. Earth Parts A/B/C 2016, 92, 52-60. [CrossRef]

20. Lv, X.G. Wetland Ecosystem Study in China; Hebei Science and Technology Publishing House: Shijiazhuang, China, 2008; p. 1.

21. Mulligan, G.F.; Partridge, M.D.; Carruthers, J.I. Central place theory and its reemergence in regional science. Ann. Reg. Sci. 2012, 48, 405-431. [CrossRef]

22. Lu, D.D. Formation and dynamics of the "Pole-Axis" spatial system. Acta Geogr. Sin. 2002, 22, 1-6.

23. Karlson, M.; Mörtberg, U.; Balfors, B. Road ecology in environmental impact assessment. Environ. Impact Assess. Rev. 2014, 48, 10-19. [CrossRef]

24. Yang, X.; Tang, L.; Jia, Y.; Liu, J. Ecological Risk Assessment of the Southern Fujian Golden Triangle in China Based on Regional Transportation Development. Sustainability 2018, 10, 1861. [CrossRef]

25. Wang, M.; Hu, K.; Zhang, D.; Lai, J. Speciation and Spatial Distribution of Heavy Metals (cu and Zn) in Wetland Soils of Poyang Lake (China) in Wet Seasons. Wetlands 2017, 9, 411. [CrossRef]

26. Dai, L.J.; Wang, L.Q.; Li, L.F.; Liang, T.; Zhang, Y.Y.; Ma, C.X.; Xing, B.S. Multivariate geostatistical source identification of heavey metals in the sediment of Poyang Lake in China. Sci. Total Environ. 2018, 621, 1433-1444. [CrossRef]

27. Zhang, H.; Jiang, Y.; Ding, M.; Xie, Z. Level, source identification, and risk analysis of heavy metal in surface sediments from river-lake ecosystems in the Poyang Lake, China. Environ. Sci. Pollut. Res. 2017, 24, 21902-21916. [CrossRef]

28. Wang, M.; Liu, J.; Lai, J. Metals Pollution and Ecological Risk Assessment of Sediments in the Poyang Lake, China. Bull. Environ. Contam. Toxicol. 2019, 102, 511-518. [CrossRef]

29. Kumar, V.; Parihar, R.D.; Sharma, A.; Bakshi, P.; Sidhu, G.P.S.; Bali, A.S.; Karaouzas, I.; Bhardwaj, R.; Thukral, A.K.; Gyasi-Agyei, Y.; et al. Gobal evaluation of heay metal content in surface water bodies: A meta-analysis using heavy metal pollution indices and multivariate statistical analysis. Chemosphere 2019, 236, 124364. [CrossRef] 
30. He, C.; Liu, J.; Li, J.; Liang, X.; Chen, X.-P.; Lei, Y.-R.; Zhu, D. Spatial distribution, source analysis, and ecological risk assessment of DDTs in typical wetland surface soils of Poyang Lake. Environ. Earth Sci. 2012, 68, 1135-1141. [CrossRef]

31. Song, C.; Liu, D.; Song, Y.; Yang, G.; Wan, Z.; Li, Y.; Xu, X. Effect of exogenous phosphorus addition on soil respiration in Calamagrostis angustifolia freshwater marshes of Northeast China. Atmos. Environ. 2011, 45, 1402-1406. [CrossRef]

32. Wang, G.-D.; Wang, M.; Yuan, Y.; Lu, X.-G.; Jiang, M. Effects of sediment load on the seed bank and vegetation of Calamagrostis angustifolia wetland community in the National Natural Wetland Reserve of Lake Xingkai, China. Ecol. Eng. 2014, 63, 27-33. [CrossRef]

33. Zhang, L.; Song, C.; Zheng, X.; Wang, D.; Wang, Y. Effects of nitrogen on the ecosystem respiration, CH4 and $\mathrm{N} 2 \mathrm{O}$ emissions to the atmosphere from the freshwater marshes in northeast China. Environ. Earth Sci. 2006, 52, 529-539. [CrossRef]

34. Zhu, H.; Yan, B.X. Export of phosphorous from paddy field and its transport process in Sanjiang Plain. Wetl. Sci. 2010, 8, 266-272.

35. Yao, Y.L.; Wang, L.; Lv, X.G.; Yu, H.X. Assessing the sensitivity of runoff to climate change in Naoli River Watershed, Northeast China. Geogr. Res. 2012, 31, 409-416.

36. Yao, Y.L.; Lv, X.G.; Wang, L.; Yu, H.X. A quantitative analysis of climate change impacts on runoff in Naoli River. Adv. Water Resour. 2010, 21, 765-770.

37. Cheng, Y.Q.; Zhang, P.Y. Regional differentiation of grain production of commodity grain bases in the Northeast China. J. Nat. Resour. 2005, 20, 925-931.

38. Liu, Z.M. Study on Runoff Evolvement and Its Driving Mechanism of Naoli River Basin in Recent 50 Years; Northeast Normal University: Changchun, China, 2012; p. 26.

39. China's Geospatial Data Cloud. Available online: http://www.gscloud.cn/ (accessed on 3 March 2020).

40. Resource and Environment Data Cloud Platform. Available online: http://www.resdc.cn/ (accessed on 3 March 2020).

41. Wu, J.S.; Liu, H.; Peng, J.; Ma, L. Hierarchical structure and spatial pattern of China's urban system: Evidence from DMSP/OLS nightlight data. Acta Geogr. Sin. 2014, 69, 759-770.

42. Xu, X.; Xu, L.; Yan, L.; Ma, L.; Lu, Y. Integrated regional ecological risk assessment of multi-ecosystems under multi-disasters: A case study of China. Environ. Earth Sci. 2015, 74, 747-758. [CrossRef]

43. Wang, H.; Song, C.C. Regional ecological risk assessment of wetlands in the Sanjiang Plain. Prog. Geogr. 2019, 38, 872-882.

44. Landis, W.; Wiegers, J.K. Ten Years of the Relative Risk Model and Regional Scale Ecological Risk Assessment. Hum. Ecol. Risk Assess. Int. J. 2007, 13, 25-38. [CrossRef]

45. Wang, W.J.; Zhang, S.W.; Li, Y.; Bu, K. Quantitative assessment of soil erosion in Sanjiang Plain based on GIS and USLE. J. Arid Land Resour. Environ. 2008, 22, 112-117.

46. Xie, G.D.; Lu, C.X.; Leng, Y.F.; Zheng, D.; Li, S.C. Ecological assets valuation of the Tibetan Plateau. J. Nat. Resour. 2003, 18, 189-196.

47. Xue, Z.S.; Jiang, M.; Lv, X.G.; Liu, X.H.; Zhao, D.Y. Influence of agricultural exploitation on ecosystem services: A case study on Middle and Lower Reaches of Nongjiang River and Bielahong River in the Sanjiang Plain. Wetl. Sci. 2012, 10, 40-45.

48. Di, X.H.; Hou, X.Y.; Xu, X.L.; Wu, L. Study on spatial-temporal characteristics of ecosystem service value in Shandong Province. Geogr. Geo-Inf. Sci. 2013, 29, 116-120.

49. Zhao, L.; Liu, J.; Tian, X. The temporal and spatial variation of the value of ecosystem services of the Naoli River Basin ecosystem during the last 60 years. Acta Ecol. Sin. 2013, 33, 3169-3176. [CrossRef]

50. Zhuang, D.F.; Liu, J.Y. Study on the model of regional differentiation of land use degree in China. J. Nat. Resour. 1997, 12, 105-111.

51. Fu, Q.; Wang, Z.L.; Liang, C. Application of multi-variate auto-regression model to forecast water demand of well irrigated paddy. J. Hydraul. Eng. 2002, 8, 107-112.

52. Liu, Z.Q.; Lv, X.G.; Liu, H.Y. Study on ecological fragility of wetlands in Sanjiang Plain. J. Geogr. Sci. 2000, 10, 151-158.

53. Liu, Z.; Liu, H.; Lu, X. [Ecological fragility of wetlands in Sanjiang Plain]. Ying Yong Sheng Tai Xue Bao (J. Appl. Ecol.) 2001, 12, 241-244. 
54. Liu, Z.-M.; Xia, G.-L.; Lv, X.-G.; Cheng, Z.-K. Response of Water Cycle Processes in Sanjiang Plain to Human Activities and Climate Change in Recent 50 Years. South-to-North Water Divers. Water Sci. Technol. 2011, 9 , 68-74. [CrossRef]

55. Li, S.C.; Zhang, C.Y.; Liu, J.L.; Zhu, W.B.; Ma, C.; Wang, J. The tradeoffs and synergies of ecosystem services: Research progress, development trend, and themes of geography. Geophys. Res. 2013, 32, 1379-1390.

56. Li, Q.-K.; Hu, Y.; Sun, J. Migration and transformation of agricultural non-point source pollutants in drainage ditches. Chin. J. Eco-Agric. 2010, 18, 210-214. [CrossRef]

57. Wu, X.N.; Fu, D.G.; Duan, C.Q. Effects of planting modes and agriculture drainage ditches on runoff nitrogen and phosphorous concentration in Chaihe Watershed. J. Soil Water Conserv. 2016, 30, 38-42.

(C) 2020 by the authors. Licensee MDPI, Basel, Switzerland. This article is an open access article distributed under the terms and conditions of the Creative Commons Attribution (CC BY) license (http://creativecommons.org/licenses/by/4.0/). 